\title{
Effect of Hot Working Parameters on Microstructure Evolution and Mechanical Properties of Ausformed Austempered Ductile Iron
}

\author{
Mohamed Soliman ${ }^{1, a^{*}}$, Adel Nofal ${ }^{2, b}$ and Heinz Palkowski ${ }^{1, c}$ \\ ${ }^{1}$ Institute of Metallurgy, Clausthal University of Technology, D38678 Clausthal-Zellerfeld, Germany \\ ${ }^{2}$ Central Metallurgical Research and Development Institute - CMRDI, Helwan, 11421 Cairo, Egypt \\ amohamed.soliman@tu-clausthal.de, badel.nofal@hotmail.com, cheinz.palkowski@tu-clausthal.de
}

Keywords: Ductile iron, austempering, ausforming, thermo-mechanical processing, transformation kinetics.

\begin{abstract}
Three ductile irons with different aluminum- and manganese-content were subjected to two thermo-mechanical schedules. In the first schedule, a total deformation of $\varphi_{t}=0.3$ is applied on the ductile irons in the austenitic region before the austempering process. In the second schedule, the materials are subjected to deformation of 0.2 in the austenitic region and deformation of 0.1 during austempering (ausforming). Mechanical deformation of austenite prior to the transformation "stage I" pronouncedly accelerated the transformation due to increasing the nucleation sites of ausferrite. This increase has its impact on enhancing the microstructural uniformity and refining the ausferrite platelets. On the other hand, the retained austenite content was not significantly affected by the applied ausforming. Remarkable increase in hardness, strength and ductility of the ausformed ductile iron due to the latter effects is observed.
\end{abstract}

\section{Introduction}

Since the discovery of the austempered ductile iron (ADI) and its first commercialization in $1972[1,2]$, many modifications in technology of heat treatment leading to cost saving and/or properties improvement were proposed [3, 4]. One of these modifications is the AusformedAustempered Ductile Iron - AADI [5,6]. The ausforming process in the AADI is introduced into the austempering schedule just after quenching but before any substantial transformation of austenite. It is shown that ausforming could provide mechanical driving force in the form of strain defects in addition to the chemical thermodynamic driving force. This can be used to accelerate the rate of stage I of austempering. The enhanced nucleation rate of ausferrite and C-enriched austenite leads to finer and more homogeneous ausferrite, which in turn, results in a dramatic increase in strength, hardness and wear resistance [7, 8].

In the framework of the current study, hot deformation in the austenitic region after austenitization is combined with ausforming process to produce thermo-mechanically processed ausformed austempered ductile iron. The effect of ausforming on the microstructure development, hardness and compression properties is investigated.

\section{Experimental Procedure}

\section{Studied Material}

Three ductile irons with different aluminium and manganese contents were investigated. The chemical composition of the alloys is given in Table 1. Melting was performed in an induction furnace. The base irons were treated with a $9.5 \mathrm{wt} \% \mathrm{MgFeSi}$ alloy for spheroidisation followed by post-inoculation with $75 \mathrm{wt} \% \mathrm{FeSi}$. The material was cast in sand molds in form of Y-blocks having the dimensions of $200 \times 150 \times 20 \mathrm{~mm}^{3}$. The matrices of the as cast microstructures are comprising of ferritic and pearlitic phases as given elsewhere [9]. 
Table 1 Composition of the ductile irons [wt.\%]

\begin{tabular}{|c|c|c|c|c|c|c|c|c|c|c|c|}
\hline Alloy & $\mathrm{C}$ & $\mathrm{Si}$ & $\mathrm{Mn}$ & $\mathrm{Al}$ & $\mathrm{Mg}$ & $\mathrm{S}$ & $\mathrm{P}$ & $\mathrm{Ni}$ & $\mathrm{Cu}$ & $\mathrm{Mo}$ & $\mathrm{Cr}$ \\
\hline $\mathrm{A}$ & 3.68 & 2.48 & 0.29 & $\mathbf{0 . 3 1}$ & 0.035 & 0.011 & 0.029 & 0.032 & 0.015 & 0.031 & 0.093 \\
\hline $\mathrm{B}$ & 3.57 & 2.59 & 0.33 & $\mathbf{0 . 9 6}$ & 0.046 & 0.011 & 0.025 & 0.011 & 0.013 & 0.036 & 0.075 \\
\hline $\mathrm{C}$ & 3.64 & 2.53 & $\mathbf{0 . 7}$ & $\mathbf{0 . 9 7}$ & 0.050 & 0.016 & 0.023 & 0.013 & 0.019 & 0.042 & 0.081 \\
\hline
\end{tabular}

\section{Thermo-Mechanical Processing and Dilatometry}

For thermo-mechanical processing and dilatometric study, a Baehr Dil 805D thermo-mechanical simulator, shown in Fig. 1, was used. The thermo-mechanical simulation was performed on cylindrical samples of $5 \mathrm{~mm}$ diameter and $10 \mathrm{~mm}$ length. Sheathed type $\mathrm{S}$ "Pt/Pt-10\% $\mathrm{Rh}$ " thermocouples with a nominal diameter of $0.2 \mathrm{~mm}$ were individually spot welded to the specimens' surface in central position. The sample was mounted horizontally between two SiN stamps. The thermal cycles were performed under vacuum of $0.005 \mathrm{~Pa}$ by inductive heating using a high frequency (HF) generator. Helium was used for cooling. The stamps are not directly heated by induction field and therefore the specimen temperature at the stamps is always lower than that in the middle of the specimen because of heat transfer to the stamps. This results in a temperature gradient towards the stamps. To overcome this problem, two molybdenum disks $(\phi 8 \times 0.36 \mathrm{~mm})$ were spot welded at the parallel ends of the samples to reduce this gradient. Using this method, the specimen temperature was homogenized within $+/-7 \mathrm{~K}$. The Mo disks also reduce friction during the compression test, i.e. serve as a lubricant and so improve the homogeneity of deformation. The dimension variations of the specimens during the thermal-deformation cycle are transmitted via a moving quartz pushrod to a LVDT sensor. A computer and data acquisition system recorded the dilatometric change, temperature and load as a function of time, and cross correlated the relative change in length as a function of temperature.

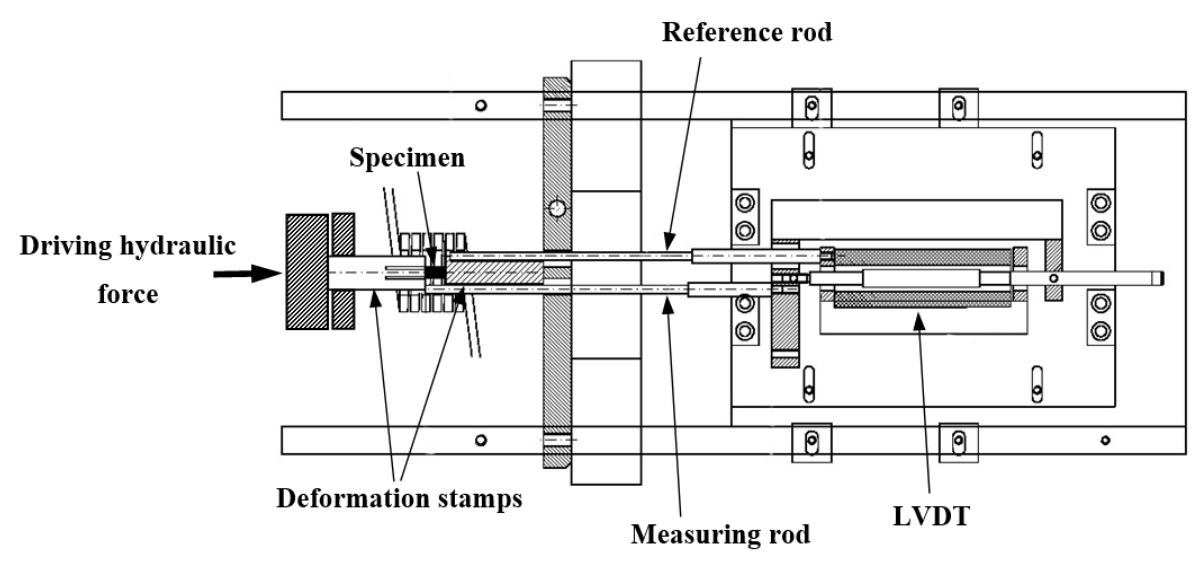

Fig. 1 Schematic drawing of the deformation dilatometer Dil 805D

The specimens were subjected to thermo-mechanical schedules shown in Fig. 2. In these schedules, the specimens were heated up to $960^{\circ} \mathrm{C}$ and subjected to two deformation steps at $960^{\circ} \mathrm{C}$ and $940^{\circ} \mathrm{C}$. The main objective of these deformation steps is to refine the structure through work hardening, recovery and recrystallization effects in austenite. The very slow deformation rate of $0.5 \mathrm{~s}^{-1}$ is adopted to minimize the susceptibility of the specimen to cracking by decreasing the strain hardening effect during deformation [10]. After the last deformation step in the austenite region, the material is quenched to isothermal holding temperature $\mathrm{T}_{\mathrm{A}}$ of $375^{\circ} \mathrm{C}$ to obtain ausferritic structure. In schedule $1(\mathrm{~S} 1)$ a total deformation of $\varphi_{\mathrm{t}}=0.3$ is applied on the DI in the austenitic region. In schedule 2 (S2): The DI is subjected to deformation in the austenitic region of 0.2 and after holding for $60 \mathrm{~s}$ at $\mathrm{T}_{\mathrm{A}}$, the $\mathrm{DI}$ is subjected to a deformation $\varphi_{\mathrm{A}}=0.1$ (ausforming). The austempering time $\mathrm{t}_{\mathrm{A}}$ corresponds to the time for the end of stage I of transformation, which is processing condition dependent as will be shown. 


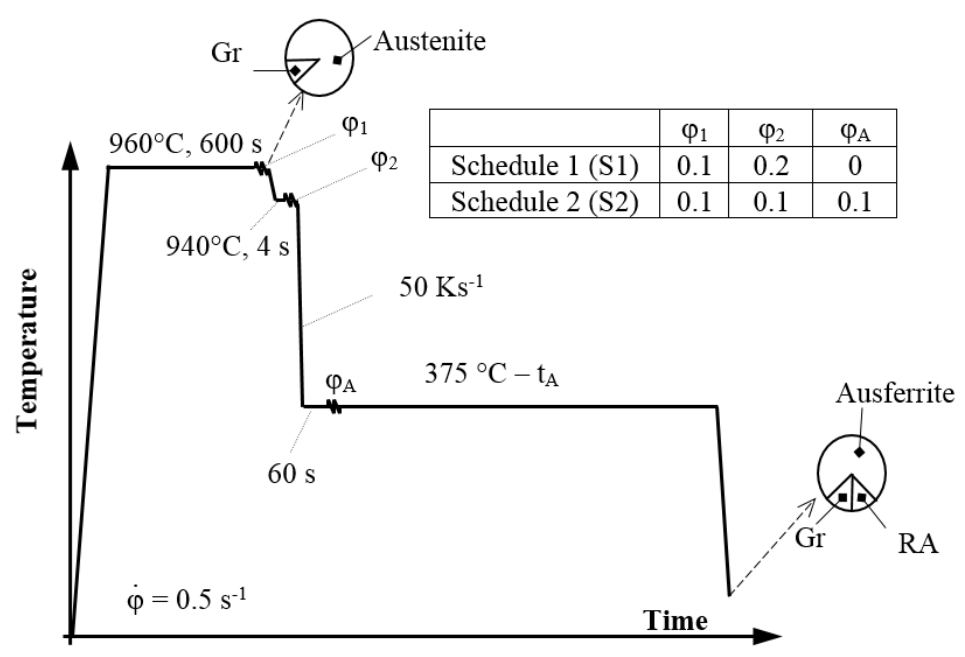

Fig. 2 Thermo-mechanical schedules applied to the four ductile irons, Gr: graphite, RA: retained austenite and $\mathrm{T}_{\mathrm{A}}$ : austempering temperature

\section{Microstructure Characterization}

The specimens were prepared by mechanical grinding followed by polishing up to a $1 \mu \mathrm{m}$ diamond paste. The microstructures were examined with an Olympus BX60M light optical microscope (LOM) after etching with $2 \%$ nital. The samples for scanning electron microscope (SEM) investigations were deep nital etched. SEM investigations were conducted on a CamScan Series 4 device. Quantitative X-ray diffraction analysis was carried out to specify the amount of retained austenite. For this purpose, polished specimens were scanned using a Siemens D5000 diffractometer, which has a goniometric diameter of $600 \mathrm{~mm}$. The experiments were conducted using a Fe-filtered $\mathrm{Co}-\mathrm{K} \alpha$ radiation diffractometer at $40 \mathrm{kV}$ and $40 \mathrm{~mA}$. The peak intensities of the whole patterns were collected by the step scanning technique utilizing small step size of $\Delta(2 \theta)=0.025^{\circ}$ and a period of $3 \mathrm{~s}$ at each fixed value of $2 \theta$ in the range between $46^{\circ}$ and $130^{\circ}$.

\section{Mechanical Characterization}

Macro-hardness testing was carried out at room temperature using Vickers hardness according to ASTM E384 applying a load of $20 \mathrm{~kg}$ (HV20). Wolpert hardness tester equipped with a digital measurement system enabling data transmission to PC. Average values of the hardness were obtained based on 5 measurements. Quasi static-compression tests were conducted in a computerized $250 \mathrm{kN}$ UTS universal testing machine at a cross head speed of $1 \mathrm{~mm} / \mathrm{min}$ on samples resulting from the simulation process.

\section{Results and Discussions}

The dilatation-time curves obtained during austempering at $375{ }^{\circ} \mathrm{C}$ of the three ductile irons are shown in Fig. 3. Deformation of austenite prior to the transformation "stage I" pronouncedly accelerated the transformation kinetics as shown in this figure. It is observable also that ausferrite transformation takes place directly after applying $\varphi_{\mathrm{A}}$. The acceleration of kinetics of ausferrite formation due to the ausforming is confirmed from the micrographs of the microstructure development shown in Fig. 4. The martensite/austenite, which is revealed by the white regions in these micrographs, is being gradually replaced by the brown sheaves. These sheaves have a lamellar structure of ferrite and austenite as will be shown by the scanning electron investigation. The lower solubility of carbon in these sheaves results in its diffusion to the surrounding austenite which stabilize. During the course of austempering, the austenite is graually enriched with the carbon rejected from the ausferrite phase. This reaction can occur until the point at which the free energy of 
ferrite is equal to the free energy of austenite; thus, at this point, no further transformation of austenite to ferrite can occur. This saturation point corresponds to the end of stage I of transformation and justify the saturation of transformation shown in Fig. 3. The residual austenite, because of its high carbon content, has a martensite start temperature (Ms) below RT; thus, a certain amount of austenite from this process can be retained at RT [12]. This residual austenite is revealed by the white regions after the course of ausferrite formation (i.e. Fig. (c) and (g) for schedules S1 and $\mathrm{S} 2$, respectively).
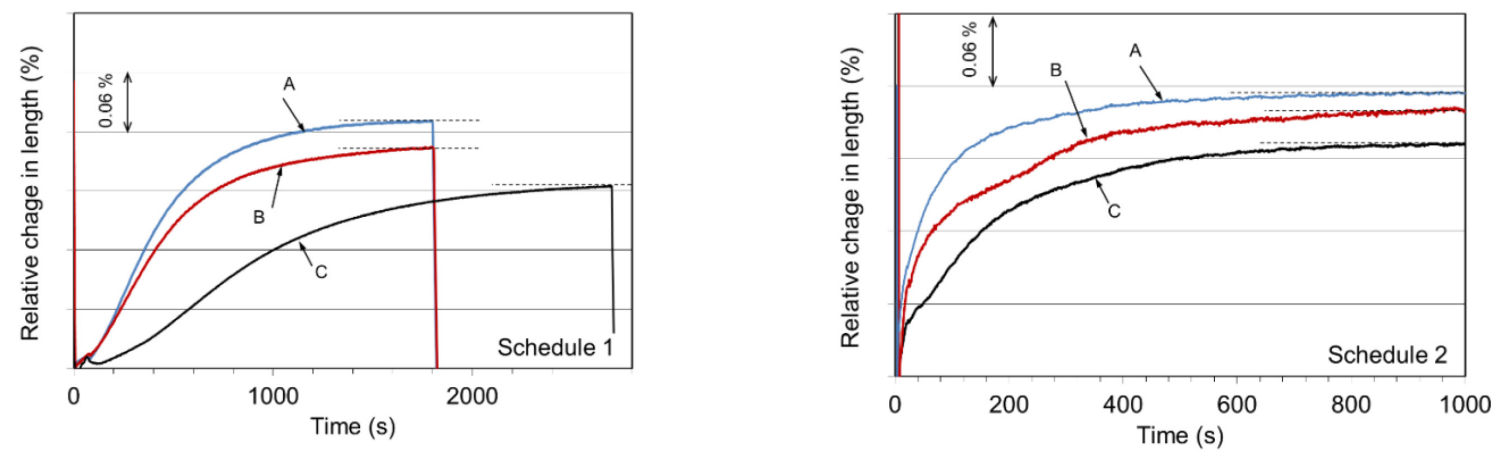

Fig.3 Dilatation-time curves obtained during austempering at $375{ }^{\circ} \mathrm{C}$
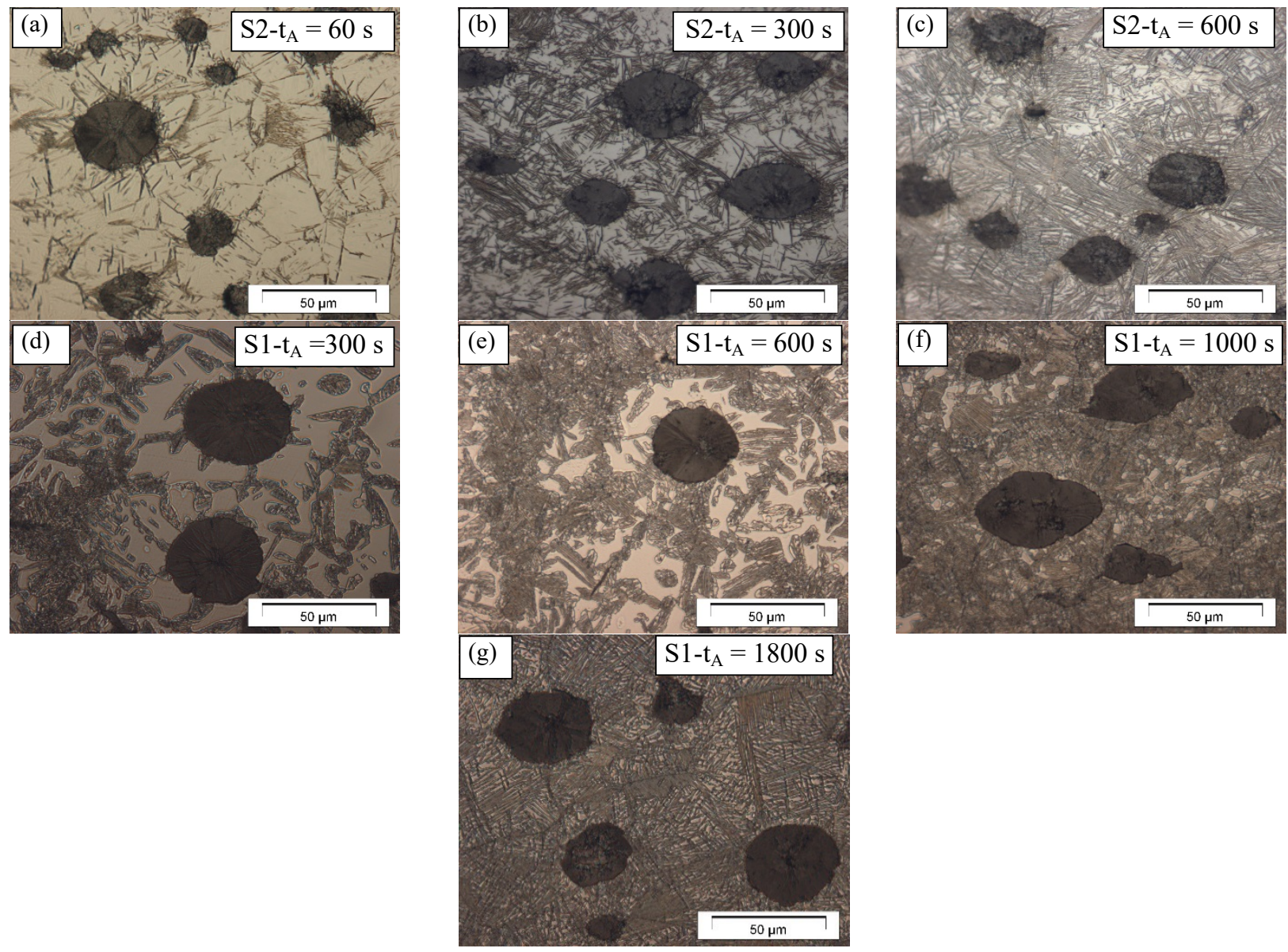

Fig. 4 Micrographs showing acceleration of the kinetics of ausferrite formation due to the ausforming process. $t_{A}$ : holding time after quenching to $T_{A}$ for schedule $S 1$ and after applying the ausforming step for stage 2. Material: ductile iron " $A$ "

The transformation from austenite into ausferrite (completing stage I of transformation) took about $1800 \mathrm{~s}$ for ductile iron "A" when subjecting it to "S1". Ausforming this alloy (schedule "S2") results in reducing the time required to complete stage I of transformation to about $600 \mathrm{~s}$. The ausforming process results in increasing the nucleation sites of ausferrite to great extent. This increase has also its impact on enhancing the microstructural uniformity and refining the ausferrite 
platelets as shown in Fig. 5. This figure enables distinguishing individual ferrite plates within the sheaves revealed using LOM in Fig. 4. It is observable in this figure that the ferrite aggregates build up from alternating ferrite/austenite plates in the same crystallographic orientation. Myszka et al. reported that isothermal transformation of ausferrite refines the ferrite plates which tend to form a typical feathery pattern indicating the direction of the plate growth [12]. It is obvious in Fig. 5 also that the retained austenite is present in a form of homogenously distributed films along ferrite plate boundaries as well as in a form of small isolated austenite colonies. The samples subjected to schedule S2 revealed blocky austenite of smaller size. On the other hand, the hot working has an influence on the matrix/graphite contact. Separation of graphite from the matrix was observed in all thermomechanically processed samples as revealed by the SEM analysis (arrows in Fig. 5). Table 2 shows that the retained austenite of the ductile iron has not significantly increased due to the applied ausforming process. The compression properties of the ductile irons are also compared in this table. The remarkable increase in hardness, strength and ductility of the ausformed ductile irons is due to the structure refinement associated with the ausforming process.
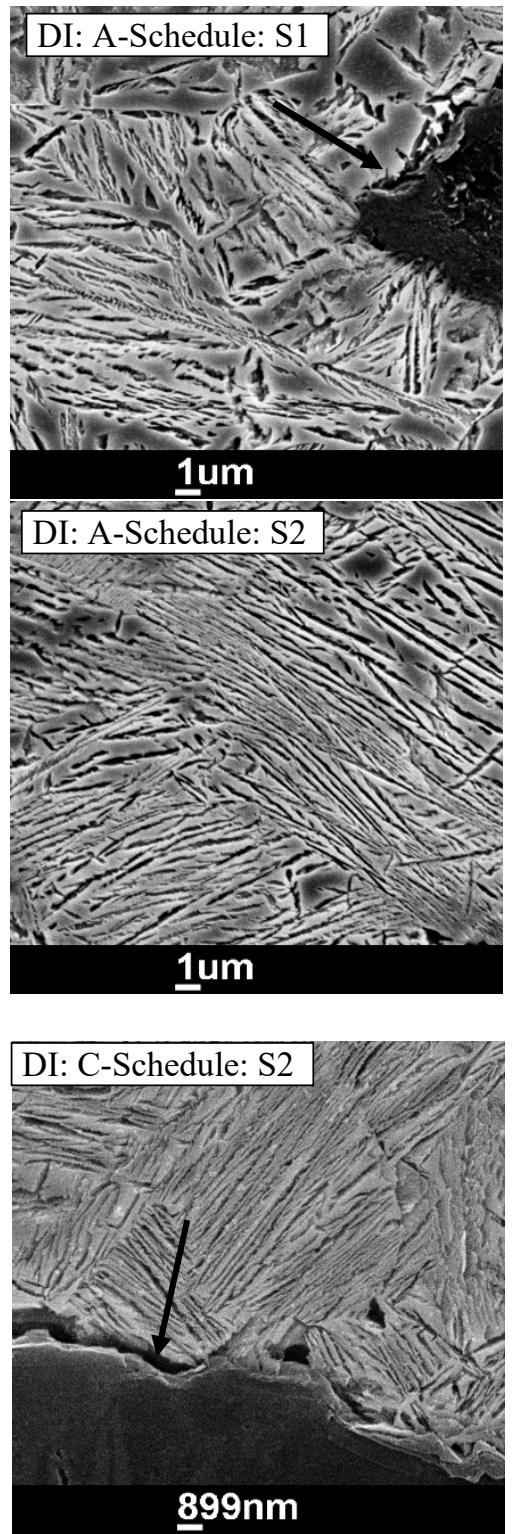
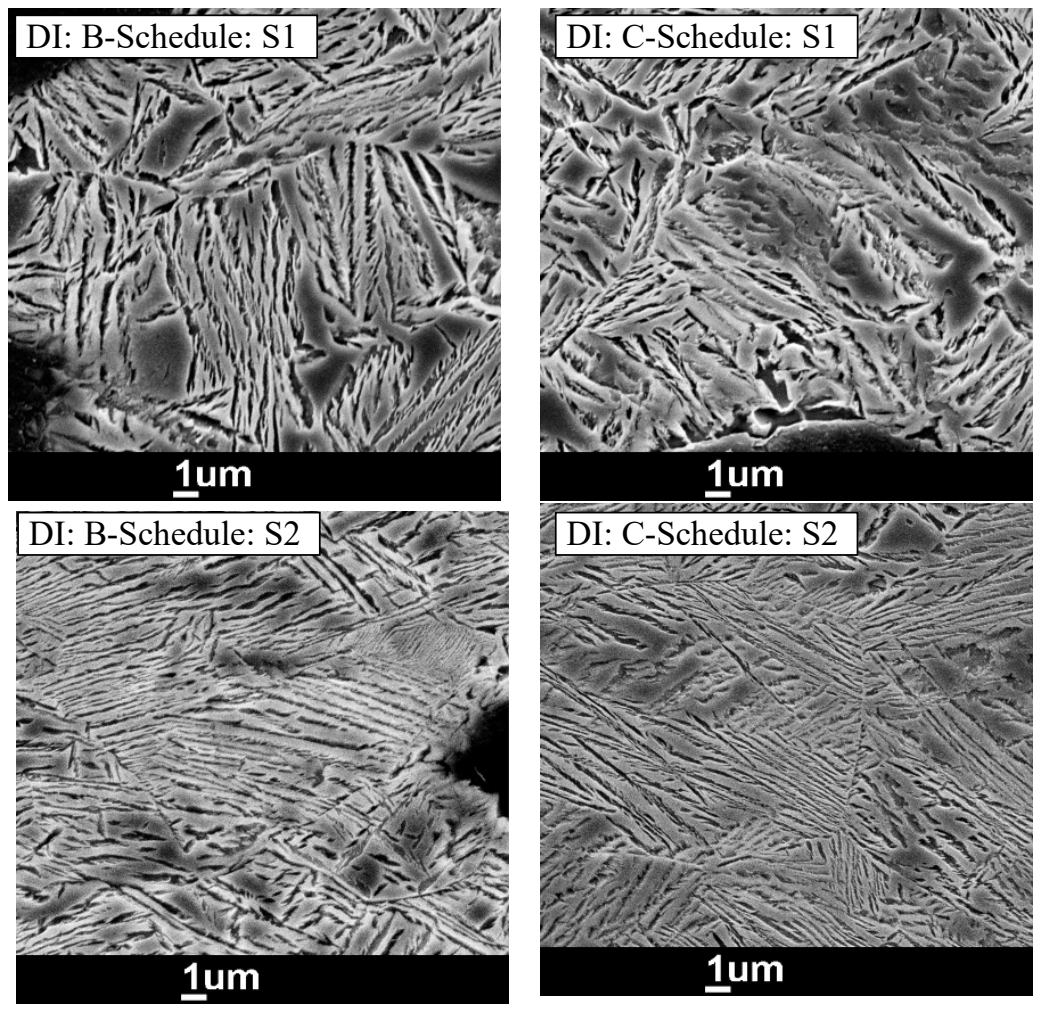

Fig. 5 Micrographs showing the refinement of the ausferrite structures due to the ausforming process of the three studied alloys 
Table 2 Mechanical characteristics of the DIs after subjecting them to schedules S1 and S2 together with their retained austenite (RA) content of the studied ductile irons. CS: Compression strength;

YS: Yield strength in compression; FS: Fracture strain; RA\%: Retained austenite percentage

\begin{tabular}{|c|c|c|c|c|c|c|}
\hline \multicolumn{2}{|c|}{} & HV20 & CS [MPa] & YS [MPa] & FS [-] & RA\% \\
\hline \multirow{2}{*}{ A } & S1 & 301 & 1447 & 689 & 0.46 & 42.2 \\
\cline { 2 - 7 } & S2 & 356 & 1671 & 960 & 0.58 & 43.1 \\
\hline \multirow{2}{*}{ B } & S1 & 335 & 1429 & 662 & 0.35 & 39.3 \\
\cline { 2 - 7 } & S2 & 350 & 1521 & 887 & 0.48 & 39.1 \\
\hline \multirow{2}{*}{ C } & S1 & 361 & 1401 & 642 & 0.352 & 44.7 \\
\cline { 2 - 7 } & S2 & 411 & 1499 & 902 & 0.39 & 47.4 \\
\hline
\end{tabular}

\section{Conclusions}

Ausforming the ductile iron pronouncedly accelerated the transformation of austenite into ausferrite. This increase has its impact on enhancing the microstructural uniformity and refining the ausferrite platelets and has insignificant effect on the retained austenite quantitiy but it results in smaller size block austenite. Such microstructural variations result in remarkable increase in hardness, strength and ductility of the ausformed ductile iron.

\section{References}

[1] A. G. F. Alabi, F. I. Aluko, Production and commercialization of austempered ductile iron, International Journal of Innovative Research \& Development, 11 (2013) 332-336.

[2] Inc QIT-Fer et Titane, Ductile iron data for design engineers ring-bound, Ductile Iron Group, 1990.

[3] A. Krzyńska , A. Kochański, Austenitization of ferritic ductile iron, Archives of Foundry Engineering 14 (2014) 49-54.

[4] M. Soliman, H. Palkowski and A. Nofal, Thermo-mechanically processed multi-phase ductile iron: microstructure development, Key Eng. Mat., 457 (2011) 199-204.

[5] Olson, B.N., Brucke, Ch., Parolini, J., Moore, D.J. \& Rundmann, K.B. Ausformed-austempered ductile iron (AADI). International Conference on ADI; DIS and AFS, Louisville, KY, USA, 29-60 (2002) 25-27.

[6] Nasr El-din, H., Nofal, A. \& Ibrahim, M., Ausforming of austempered ductile iron alloyed with nickel., Int. J. Cast Metal Res. 19 (2006) 137-150.

[7] A. Nofal, Advances in the metallurgy and applications of ADI, J. Metall. Eng. 2 (2013) 1-18.

[8] A. Nofal, The current status of the metallurgy and processing of austempered ductile iron (ADI), 10th International Symposium on the Science and Processing of Cast Iron (SPCI 10), (2014) (Mar del Plata Argentina), INTEMA-Argentina

[9] M. Soliman, A. Nofal, H. Palkowski, Alloy and process design of thermo-mechanically processed multiphase ductile iron, Materials and Design, 89 (2015) 450-465.

[10] Dieter G.E, Kuhn H.A and Semiatin S. L, Handbook of Workability and Process Design, First printing, ASM International, Materials Park, OH, USA,2003.

[11] D. Myszka, E. Skołek, A. Wieczorek, Manufacture of toothed elements in nanoausferritic ductile iron, Arch. Metall. Mater. 59 (2014) 1217-1221. 